but a further rise in the temperature did not increase the shoot number, whereas $H$. psittacorum plants produced even more shoots at 21C (Geertsen, 1989). This result corresponds with the fact that $H$. aurantiaca is indigenous to areas with slightly cooler conditions than $H$. psittacorum: $H$. aurantiaca is found in southern Mexico to central Costa Rica up to an altitude of $800 \mathrm{~m}$, whereas $H$. psittacorum is found in the northern part of South America, just around the equator (Andersson, 1985).

According to the current results, the earliest flowering of $H$. aurantiaca is achieved when plants are exposed to short days (8 hr) and high temperature $(21 \mathrm{C})$. But the experiment raises new questions: 1) how many weeks of short days are necessary to initiate flowering; 2) is there a stage at which the stimulus is most effective; 3 ) does the period of exposure to short days have any influence on flowering characteristics; and 4) how long a period is necessary for floral development?

\section{Literature Cited}

Andersson, L. 1985. Revision of Heliconia subgen. Stenochlamys (Musaceae-Heliconioideae). Op- era Botanica 82: 1-124.

Broschat, T. K., H. Donselman, and A.A. Will. 1984. 'Andromeda' and 'Golden Torch' Heliconias. HortScience 19(5):736-737.

Criley, R.A. 1985. Heliconia, p. 125-128. In: A Halevy (ed.). Handbook of flowering. CRS, Boca Raton, Fla.

Criley, R.A. and O. Kawabata. 1986. Evidence for a short-day flowering response in Heliconia stricta 'Dwarf Jamaican'. HortScience 21(3):506-507.

Geertsen, V. 1989. Effect of photoperiod and temperature on the growth and flower production of Heliconia psittacorum 'Tay'. Acts Hort. 252:117-122. (In press.)

\title{
Chlormequat Chloride Growth Retardant Reduces Spider Mite Infestations of Hibiscus rosa-sinensis
}

\author{
L.S. Osborne ${ }^{1}$ and A.R. Chase ${ }^{2}$ \\ University of Florida, IFAS, Central Florida Research and Education \\ Center, 2807 Binion Road, Apopka, FL 32703
}

Additional index words. integrated pest management, CCC

\begin{abstract}
Hibiscus rosa-sinensis L. plants treated three times with $850 \mathrm{mg} \cdot \mathrm{liter}^{-1}$ of the growth retardant chlormequat chloride (CCC) were less susceptible to infestation with Tetranychus urticae (Koch) than water-treated control plants. The difference in mite numbers was noted within 8 days after releasing mites onto test plants. Mean number of mites per treated plant was 3.7, compared to 30 on nontreated plants. This activity was observed on all treated plants 6 months after applying CCC. Significant differences were observed on treated plants that were defoliated and allowed to produce new foliage before being evaluated. Therefore, surface chemical residues were not responsible for reducing mite infestations on CCC-treated plants.
\end{abstract}

Growth regulators are used on a wide variety of ornamental crops to improve rooting, increase shoot formation, shorten internodes, and induce flowering. The effects of some of these compounds on pests have been investigated on many crops. Chlormequat chloride (CCC) has been shown to suppress fecundity, feeding, survival, and population development of numerous aphid species (Tahori et al., 1965c; van Emden, 1964, 1969), Lepidoptera (Tahori et al., 1965b; Zummo et al., 1984), and the greenhouse whitefly (Fischer and Shanks, 1979). The action that CCC has on aphids may result from a decrease in the nutritive quality of treated plants (van Emden, 1969). Not all effects observed have been negative. Fischer and Shanks (1979) observed that whitefly infestations increased on the poinsettia variety 'Eckespoint

Received for publication 3 Oct. 1988. Published as Florida Agricultural Experiment Stations Journal Series no. 9572. The cost of publishing this paper was defrayed in part by the payment of page charges. Under postal regulations, this paper therefore must be hereby marked advertisement solely to indicate this fact.

'Associate Professor of Entomology.

${ }^{2}$ Professor of Plant Pathology.
C-1', even though a reduction was noted on 'Annette Hegg Lady'.

Grower observations regarding twospotted spider mite (TSM) populations on Hibiscus rosa-sinensis led to the study described here. Because obvious alterations in leaf appearance occur after CCC treatment and because TSM reacts to slight differences in leaf variegation or structure (Osborne and Chase, 1985), the potential for differential susceptibility of hibiscus to infestation by TSM exists. Effects of CCC treatment on infestations by TSM on hibiscus were evaluated.

Rooted cuttings were obtained from growers and established in potting medium consisting of equal volumes of steam-treated (90C for $1.5 \mathrm{hr}$ ) Canadian peat and pine bark. The medium was amended with $\left(\mathrm{kg} \cdot \mathrm{m}^{-3}\right) 3.6$ Osmocote 19:6:12 (slow-release fertilizer, Sierra Chemical, Milpitas, Calif.), 2.7 dolomite, and 0.5 Micromax micronutrient (Sierra Chemical). Plants were grown in 10$\mathrm{cm}$-diameter (0.8-liter) plastic pots in a glasshouse at 18 to $33 \mathrm{C}$ and maximum light level of $350 \mu \mathrm{mol} \cdot \mathrm{s}^{-1} \cdot \mathrm{m}^{-2}$. Unless otherwise noted, each test consisted of two treatments with 10 plants being treated with water only and 10 with CCC (American Cy - anamid, Wayne, N. J.) three times at weekly intervals starting no sooner than 3 weeks after potting. Chlormequat chloride was applied to runoff at the rate of $850 \mathrm{mg} \cdot$ liter $^{-1}$.

An initial study (Test 1) was conducted to test the hypothesis that CCC-treated hibiscus plants were less susceptible to mites than nontreated plants. Treatments were applied on 15, 22, and 29 May 1984. Plants were infested 2 days after the final treatment with five, 1- to 2-day-old adult female TSM per plant. After being infested, 10 treated and 10 control plants were randomized on a raised bench in a greenhouse. The numbers of active (motile) mites were counted 8 June 1984 (8 days after infestation).

A second study (Test 2) was conducted in order to validate the findings of Test 1 . Treatments were applied on 6, 13, and 20 July 1984. After each application, all 20 plants were randomized on a raised bench in a greenhouse infested with TSM and allowed to become naturally infested. This was done to better simulate a natural situation where mites are given an opportunity to select their own food source. No mites were observed on any plants before the final CCC application.

The number of motile mites on each plant was determined on 10 Aug. 1984. After this evaluation, plants were treated twice, with a 4-day interval with the labeled rates of the acaricide dienochlor (Pentac WP), inspected to ensure no mites were present, and then returned to the infested greenhouse. Thereafter, plants were monitored on 31 Aug. and 10 Sept. and the number of motile mites on each plant counted.

A third study (Test 3) was conducted to determine if $\mathrm{CCC}$ residues on the leaf surface were responsible for results observed in the two previous tests. Treatments were applied on 6, 13, and 20 July 1984 as described for the previous tests. Plants were defoliated by hand on 19 Sept. and allowed to produce new growth. On 6 Nov., three leaves/plant were infested with three 1-to 2-day-old adult female TSM/leaf. The numbers of motile mites were counted 14, 20, and 27 Nov.

The fourth study (Test 4) was conducted to determine if CCC activity had long-term effects. Treatments were applied to hibiscus on 13, 20, and 27 July 1984. On 10 Aug., 

on the number of motile stages of Tetranychus urticae on dates given on Hibiscus rosa-sinensis (Test 2).

\begin{tabular}{lrrr}
\hline & \multicolumn{3}{c}{ Mean no. of mites/plant } \\
\cline { 2 - 4 } Treatment & 10 Aug. & 1 Aug. & \multicolumn{1}{c}{10 Sept. } \\
\hline Water & $65 \pm 55$ a & $64 \pm 55$ a & $140 \pm 73 \cdot \mathrm{a}$ \\
CCC & $0 \pm 0$ b & $10 \pm 17$ b & $49 \pm 35$ b
\end{tabular}

${ }^{z}$ Each value is a mean of 10 plants. Plants were treated three times at weekly intervals with $\mathrm{CCC}$ at $850 \mathrm{mg} \cdot \mathrm{liter}^{-1}$ to runoff. Mean separation by Student's $t$ test, $P=0.01$.

three leaves/plant were infested with three 1to 2-day-old adult female TSM/leaf. The number of motile mites was counted 15 Aug., 5 and 13 Sept. After the final count, plants were defoliated by hand, treated with the acaricide dienochlor, and placed in a noninfected greenhouse. On 21 Jan. 1985, three leaves/plant were infested with three 1- to 2-
Table 1. Effect of chlormequat chloride (CCC)

day-old adult female TSM. The numbers of motile mites were counted 31 Jan., 7 and 15 Feb.

A final study (Test 5) was conducted and population development followed through time on both CCC- and water-treated plants. Ten plants each were treated with $\mathrm{CCC}$ or with water as described for the previous tests. Treatments were applied on 24 and 31 Aug. and 7 Sept. 1984. After each treatment was applied, all 20 plants were randomized on a raised bench in a greenhouse infested with TSM and allowed to become naturally infested. The number of motile mites on each plant was determined weekly beginning 30 Aug.

The mean number of motile mites per CCCtreated plant in Test 1 was 3.7, compared to 30 for nontreated plants $(P=0.01)$. Two CCC-treated plants had no mites and seven of 10 CCC-treated plants had fewer mites after 8 days than were originally released

Table 2. Effect of chlormequat chloride (CCC) on the number of motile stages of Tetranychus urticae on Hibiscus rosa-sinensis following treatment (Test 3).

Mean no. of mites/leaf

after no. of weeks indicated

\begin{tabular}{lcccc}
\cline { 2 - 5 } Treatment & 0 & 1 & 2 & 3 \\
\hline Water & $3 \pm 0 \mathrm{a}$ & $8 \pm 3 \mathrm{a}$ & $109 \pm 32 \mathrm{~b}$ & $99 \pm 23 \mathrm{~b}$ \\
CCC & $3 \pm 0 \mathrm{a}$ & $11 \pm 6 \mathrm{a}$ & $60 \pm 27 \mathrm{a}$ & $46 \pm 18 \mathrm{a}$
\end{tabular}

${ }^{2}$ All values are a mean number of mites/leaf with three leaves being sampled on each of 10 plants/ treatment. Plants were treated three times at weekly intervals with CCC at $850 \mathrm{mg}$-liter to runoff. Mean separation by Student's t test, $P=0.01$.

Table 3. Effect of chlormequat chloride (CCC) on the number of motile stages of Tetranychus urticae on Hibiscus rosa-sinensis following treatment (Test 4).

\begin{tabular}{|c|c|c|c|c|c|c|}
\hline \multirow[b]{2}{*}{ Treatment } & \multicolumn{6}{|c|}{$\begin{array}{l}\text { Mean no. of mites/leaf } \\
\text { after no. of weeks indicated }\end{array}$} \\
\hline & 0 & 1 & 2 & 21 & 22 & 23 \\
\hline $\begin{array}{l}\text { Water } \\
\text { CĆC }\end{array}$ & $\begin{array}{l}17 \pm 5 a \\
13 \pm 4 a\end{array}$ & $\begin{aligned} 149 & \pm 80 \mathrm{~b} \\
26 & \pm 25 \mathrm{a}\end{aligned}$ & $\begin{array}{l}519 \pm 433 b \\
280 \pm 120 a\end{array}$ & $\begin{aligned} 23 & \pm 16 \mathrm{~b} \\
7 & \pm 11 \mathrm{a}\end{aligned}$ & $\begin{aligned} 115 & \pm 87 b \\
30 & \pm 23 a\end{aligned}$ & $\begin{aligned} 165 & \pm 102 b \\
43 & \pm 102 a\end{aligned}$ \\
\hline
\end{tabular}

${ }^{2}$ All values are a mean number of mites/leaf with three leaves being sampled on each of 10 plants/ treatment. Plants were treated three times at weekly intervals with CCC at $850 \mathrm{mg} \cdot$ liter $^{-1}$ to runoff. At the end of week 3 all leaves were removed from plants and new growth was allowed to be produced. Plants were reinfested with three mites/leaf during week 19. Mean separation by Student's $t$ test, $P=$ 0.01

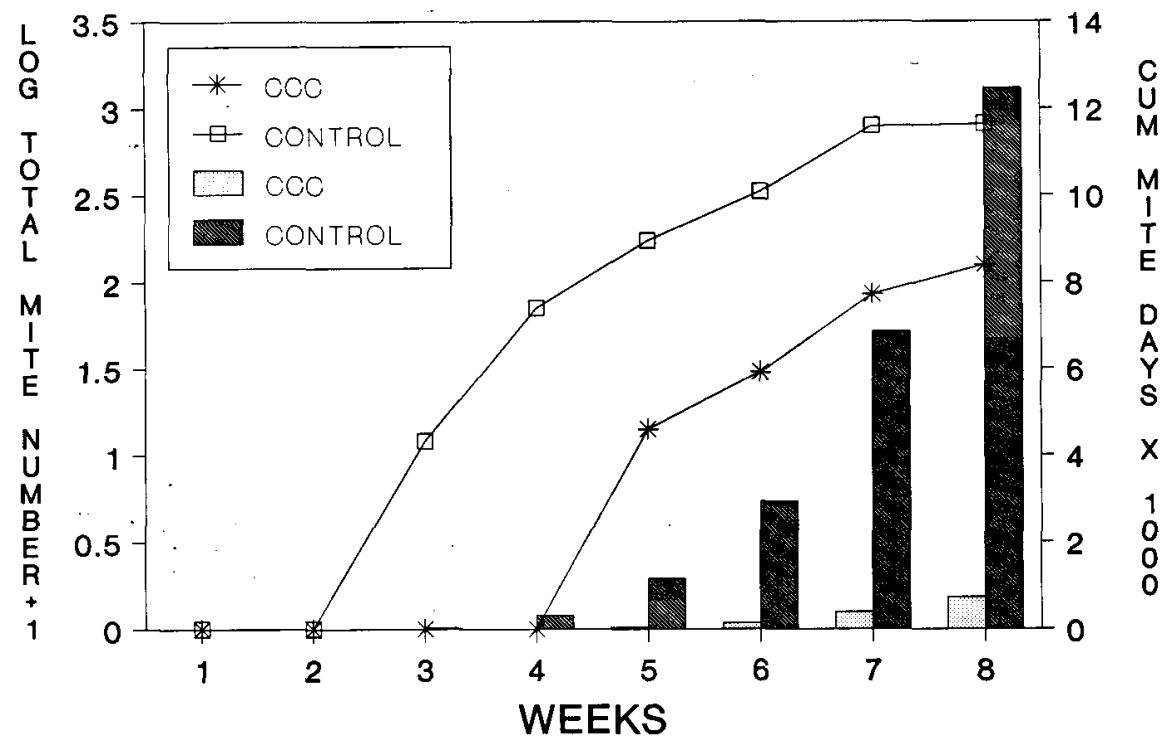

Fig. 1. The effect of chlormequat chloride (CCC) on the $\log$ total $(+1)$ number of mites per 10 treated plants (bars) and the cumulative number of mite days (lines) (Test 5). onto the plants. These results indicate one of the following may have occurred: 1) The treated plants might have been toxic to the TSM, thus reducing their number through direct mortality; 2) treated plants may not have contained adequate nutrition, thus resulting in reduced survivorship or fecundity; 3) the treated plants may have caused the plants to repel TSM; or 4) leaves may not have contained the proper feeding stimuli, which resulted in the mites leaving the plants in search of an acceptable food source.

No mites were found on any of the CCCtreated plants in Test 2 after being placed in the infested greenhouse for about 1 month (Table 1). After all plants were disinfested with dienochlor and placed into the TSMinfested greenhouse, they soon became infested, but the number of mites on 31 Aug. and 10 Sept. was significantly less on the treated plants than on the controls. This study supports the results obtained in Test 1 and substantiates the claims made by growers that they have fewer TSM problems on hibiscus treated with CCC.

The results of Test 3 (Table 2) indicate that surface residues of CCC on the foliage are not responsible for reducing TSM population development on hibiscus. Initially, there were more mites, although not significantly, on the CCC-treated plants. However, by week 2 there were significantly more mites on control plants. By week 3 the number of mites on the control plants had somewhat decreased from that observed at week 2 , probably because the leaves began to deteriorate as a result of the high mite populations that were confined on them. The amount of leaf area available for mite feeding became a limiting factor only in the control treatments. Therefore, we believe that effects observed on mite population development were not density-related but the result of a physiological effect on the mites through the possible nutritional changes in the host plant.

The results of Test 4 support the results obtained in previous tests (Table 3 ). The counts made during the 6th month (week 23), after the last application of $\mathrm{CCC}$, indicate that the effect lasts at least a half-year. Secondly, this study confirms the results observed in Test 3 , i.e., the effect of CCC does not result from CCC surface residues on the treated leaves. In this test, all treated foliage had been removed and the effect was still observed 6 months later.

The results of Test 5 are presented in Fig. 1. No mites were observed on any plants before the 13 Sept. (week 1) evaluation. The marked difference between mite populations on the CCC-treated plants and the controls could result in significant differences in the amount of damage sustained by mite-infested plants. The lines in Fig. 1 represent the cumulative number of mite-days that were calculated using the methods used by Osborne and Petitt (1985). Mite-days, the area under the curve of mite number plotted against time, is an index of the crop protection afforded by a treatment that, in this case, is the application of CCC. The difference in 
mite-days between treated and control plants observed in this study indicates that the use of this growth regulator on hibiscus results in significant control of TSM population development. These differences and those noted by Chase et al. (1987) in the reduction of disease severity when plants were treated with CCC suggest that this material would offer significant benefits in an integrated pest management program, the major benefit being the reduced need for applying pesticide.

\section{Literature Cited}

Chase, A.R., L.S. Osborne, and J.M.F. Yuen. 1987. Effects of growth regulator chlormequat chloride on severity of three bacterial diseases on 10 cultivars of Hibiscus rosa-sinensis. Plant
Dis. 71(2):186-187.

Fischer, S.J. and J.B. Shanks. 1979. Whitefly infestation on chrysanthemum and poinsettia treated with plant and insect growth regulators. J. Amer. Soc. Hort. Sci. 104(6):829-830.

Osborne, L.S. and A.R. Chase. 1985. Susceptibility of cultivars of english ivy to two-spotted spider mite and xanthomonas leaf spot. HortScience 20:269-271.

Osborne, L.S. and F.L. Petitt. 1985. Insecticidal soap and the predatory mite, Phytoseiulus persimilis (Acari: Phytoseiidae), used in management of the twospotted spider mite (Atari: Tetranychidae) on greenhouse grown foliage plants. J. Econ. Entomol. 78:687-691.

Tahori, A.S., G. Zeidler, and A.H. Halevy. 1965b. Effect of some plant growth retardants on the feeding of the cotton leaf worm. J. Sci. Food
Agr. 16:570-571.

Tahori, A. S., A.H. Halevy, and G. Zeidler. 1965c. Effect of some plant growth retardants on the oleander aphid Aphis nerii (Boyer). J. Sci. Food Agr. 16:568-569.

van Emden, H.F. 1964. Effect of (2-chloroethyl) trimethylammonium chloride on the rate of increase of the cabbage aphid (Brevicoryne brassicae) (L). Nature (London) 201:946-947.

van Em den, H. F. 1969. Plant resistance to Myzus persicae induced by a plant regulator and measured by aphid relative growth rate. Entomol. Expt. \& Appl. 12:125-131.

Zummo, G. R., J.H. Benedict, and J.C. Segers. 1984. Effect of the plant growth regulator mepiquat chloride on host plant resistance in cotton to Bollworm (Lepidoptera: Noctuidae). J. Econ. Entomol. 77:922-924.

\section{Weed Interference in Container-grown 'San Jose' Juniper}

\author{
Kandy L. Walker ${ }^{1}$ and David J. Williams ${ }^{2}$ \\ Department of Horticulture, University of Illinois, Urbana, IL 61801
}

Additional index words. Juniperus chinensis 'San Jose', Echinochloa crusgalli,

Digitaria sanguinalis, Setaria faberi, barnyardgrass, large crabgrass, giant foxtail

\begin{abstract}
Experiments in two consecutive years indicated that barnyardgrass (Echirzochloa crusgalli $\mathbf{L}$.), large crabgrass (Digitaria sanguinalis $\mathbf{L}$.), and giant foxtail (Setaria faberi Herrm.) reduced growth of container-grown 'San Jose' juniper (Juniperus chinensis L. 'San Jose') 83 days after transplanting grass seedlings into the containers. Grass densities of one to six weeds per container reduced 'San Jose' juniper growth. By 83 days of grass interference, juniper shoot dry weight was reduced as much as $43 \%$ by six weeds per container.
\end{abstract}

There has been an increase in the number of ornamental grown in containers (Fretz, 1972; Gwynne, 1985). Along with this increase, weed control in container-grown plants has become a major economic problem (Padgett and Frazier, 1962). Slow crop growth due to weed interference can result. in poorquality plants (Fletcher, 1983) and thus lower prices achieved by growers (Davison, 1971).

Weed interference studies can help nursity on plant growth, and such research can improve growers' weed control techniques (Zimdahl, 1980). To date, only a few researchers have evaluated weed interference in container-grown crops (Fretz, 1972; Walker and Williams, 1988). We therefore determined the effects of barnyardgrass, giant

Received for publication 16 June 1989. This study was a part of Project no. S-103 of the Agricultural Experiment Station, College of Agriculture, Univ. of Illinois at Urbana-Champaign. The cost of publishing this paper was defrayed in part by the payment of page charges. Under postal regulations, this paper therefore must be hereby marked $a d$ vertisement solely to indicate this fact.

'Current address: Landis International, Inc., P.O. Box 792, Placerville, CA 95667.

${ }^{2}$ Director, Research and Development, Client Programs, and Professor. sery operators realize the effect of weed den- foxtail, and large crabgrass on the growth of

Newly rooted 'San Jose' junipers were planted in 7.6-liter polyethylene nursery containers in a 2 hardwood bark : 1 sand mixture (v/v) in 1985 and 1986. Seeds of barnyardgrass, giant foxtail, and large crabgrass were germinated in a 1 peat : 1 perlite : 1 soil medium (by volume). Two weeks after grass emergence, uniform seedlings (one- to two-leaf stage) of each species were planted into each container at densities of one to six plants per container (10 June 1985 and 2 May 1986). Twenty-one treatments were replicated four times in a randomized complete-block design (one container per treatment). Osmocote (14N-6P-11.6K),

Table 2. Orthogonal contrasts for 'San Jose' juniper growth index as influenced by densities of annual grasses 83 days after weeds were transplanted into containers.

\begin{tabular}{|c|c|c|c|c|c|c|c|c|}
\hline \multirow[b]{2}{*}{ Contrast } & \multicolumn{7}{|c|}{ Densities of grass } & \multirow{2}{*}{$\begin{array}{c}F \\
\text { value }\end{array}$} \\
\hline & 0 & 1 & 2 & 3 & 4 & 5 & 6 & \\
\hline \multicolumn{9}{|c|}{1985} \\
\hline 1 & -6 & 1 & 1 & 1 & 1 & 1 & 1 & $38.59^{*}$ \\
\hline 2 & 0 & -1 & 0 & 0 & 0 & 0 & 1 & 0.25 \\
\hline \multicolumn{9}{|c|}{1986} \\
\hline 1 & -6 & 1 & 1 & 1 & 1 & 1 & 1 & $30.37^{*}$ \\
\hline 2 & 0 & -1 & 0 & 0 & 0 & 0 & 1 & 2.11 \\
\hline
\end{tabular}

*F test significant at $P=0.05$. onset of the experiment. A soluble fertilizer $(20 \mathrm{~N}-8.6 \mathrm{P}-16.6 \mathrm{~K})$ at $200 \mathrm{mg} \cdot \mathrm{liter}^{-1} \mathrm{was}$ applied at each watering.

Growth indices growth index $=$ [height $+($ width + width $) / 2] / 2\}$ were determined three or four times through the growing season to determine when growth reduction might occur. Widths were measured in a northsouth and east-west direction. Shoots of grass weeds and junipers were harvested at the termination of the experiments. Plants were dried in a forced-air oven at $60 \mathrm{C}$ to constant weight.

'San Jose' juniper growth indices were reduced $23 \%$ in 1985 and $21 \%$ in 1986 within 83 days after transplanting grass weeds (Table 1). No differences existed between grass species in either year. There was no intercontainer-grown 'San Jose' juniper.

Table 1. 'San Jose' juniper growth index as influenced by densities of annual grasses 83 days after weeds were transplanted into containers. ${ }^{2}$

\begin{tabular}{ccc}
\hline \hline $\begin{array}{l}\text { No. of } \\
\text { weeds/ } \\
\text { container }\end{array}$ & \multicolumn{1}{c}{ Juniper growth index $(\mathrm{cm})$} \\
\cline { 2 - 3 } & 1985 & 1986 \\
\hline 0 & 27.9 & 34.2 \\
1 & 22.2 & 30.1 \\
2 & 23.1 & 30.6 \\
3 & 22.1 & 30.2 \\
4 & 22.3 & 27.2 \\
5 & 22.3 & 28.9 \\
6 & 21.6 & 28.4 \\
\hline
\end{tabular}

${ }^{2}$ Single degree of freedom orthogonal comparisons were conducted.

"Means of four replicates calculated over three grasses: barnyardgrass, giant foxtail, large crabgrass.

a slow-release fertilizer, was applied at the 